Aprilia et al./ The Effectiveness of Chronic Disease Prevention

\title{
Path Analysis on the Effectiveness of Chronic Disease Prevention Program using Health Belief Model
}

\author{
Nafi'ah Aprilia'), Didik Tamtomo²), Endang Sutisna Sulaeman²) \\ ${ }^{1)}$ Masters Program in Public Health, Universitas Sebelas Maret \\ 2)Faculty of Medicine,Universitas Sebelas Maret
}

\begin{abstract}
Background: Chronic disease prevention program is a proactive health service system on chronic diseases which can affect the hypertension control. This study aimed to determine the effect of chronic disease prevention program and the construction of Health Belief Model (HBM) on the prevention of elderly hypertension with path analysis method.

Subjects dan Method: This study used observational analytical study with retrospective cohort study approach. This study was conducted in four community health centers in Ngawi Regency, East Java, in April-May 2019. The total sample of 200 elderly aged 60-74 years was divided into2 groups, such as group which participated inchronic disease prevention program(case) and group which did not participate inchronic disease prevention program(control) based on fixed exposure sampling. The dependent variable of this study was hypertension control. The independent variables in this study were participation in chronic disease prevention program, perceived vulnerability, perceived seriousness, perceived benefits, perceived barriers, cues to action, and selfefficacy. Variable data collection used questionnaires and analyzed using path analysis.

Results: Hypertension control was directly and positively affected by chronic disease prevention $\operatorname{program}(b=2.85 ; 95 \% \mathrm{CI}=0.48$ to $5.22 ; \mathrm{p}=0.018)$, perceived vulnerability $(\mathrm{b}=1.35 ; 95 \% \mathrm{CI}=0.16$ hingga 2.53; $\mathrm{p}=0.025)$, perceived seriousness $(\mathrm{b}=0.83 ; 95 \% \mathrm{CI}=0.04$ to $1.62 ; \mathrm{p}=0.039)$, and selfefficacy $(\mathrm{b}=0.99 ; 95 \% \mathrm{CI}=0.14$ to $1.85 ; \mathrm{p}=0.023)$. Hypertension control was indirectly affected by perceived benefits, perceived barriers, and cues to action.

Conclusion: Hypertension control in the elderly is directly and positively affected by participation in chronic disease prevention program, perceived vulnerability, perceived seriousness, and selfefficacy. Hypertension control is indirectly affected by perceived benefits, perceived barriers, and cues to action.
\end{abstract}

Keywords: Hypertension, chronic disease, prevention, Health Belief Model, path analysis

Correspondence:

Nafi'ah Aprilia. Masters Program in Public Health, Universitas Sebelas Maret. Jl. Ir. Sutami 36A, Surakarta 57126, Central Java. Email: nafiahlia@gmail.com. Mobile: 082230766393

\begin{tabular}{l}
\hline BACKGROUND \\
\hline Hypertension is one of the causes of \\
mortality and morbidity without initial \\
symptoms, so that hypertension is called as \\
silent killer (Susilo, 2011; Chen and Hu, \\
2014). Hypertension can have a negative \\
effect on public health and socio-economic \\
condition in developed and developing \\
countries (Triyanto, 2014; Asibey et al., \\
2018). Hypertension can affect various ages \\
and rates of people with high hypertension
\end{tabular} above 18 years of age (Basic Health Research, 2018).

In the aging process, there are various decreases in body function both biologically and psychologically. Biological aging is characterized by a decrease in theorgans function which can be a cause of various diseases, such as hypertension.

According to Savitri (2017), one out of ten adults in the world has the potential to suffer from hypertension. The prevalence of 
Journal of Health Promotion and Behavior (2019), 4(2): 85-97

https://doi.org/10.26911/thejhpb.2019.04.02.01

hypertension in Asia continues to increase by $19.6 \%$ in 2005 , increasing to $23.1 \%$ in 2015 (Du et al., 2017). The highest prevalence of hypertension is at the age of $75^{-}$ 84 years and quite low at the age of $45^{-74}$ years in the American population of Chinese descent (Chen and $\mathrm{Hu}$, 2014).

Health awareness in Indonesia is still low, most of people with hypertension do not realize that they suffer from hypertension. The prevalence of hypertension in Indonesia has increased by $25.8 \%$ in 2013 , increasing to $34.1 \%$ in 2018. Lack of physical activity and consumption of fruits and vegetables are the cause of an increase in the prevalence of hypertension (Basic Health Research, 2018).

In 2018, the percentage of hypertension in East Java Province increased by $20.43 \%(1,828,669$ people) with a proportion of $20.83 \%$ (825,412 people) men and 20.11\% (1,003,257 people) women (East Java Provincial Health Office, 2018). Ngawi Regency, as one of the Regencies in East Java Province had a significant increase in hypertension patients in 2018 by 167,992 (Ngawi Regency Health Office, 2018).

The increasing prevalence of hypertension is the basis of the government (Asibey et al., 2018) to have hypertension control through BPJS Kesehatan (Healthcare and Social Security Agency) to reduce the increase of hypertension care costs (Ma, 2018).

The chronic disease prevention program is a means of controlling hypertension through a proactive and integrated approach involving participants, health facilities, and BPJS Kesehatan. This program aims to achieve optimal quality of life with effective and efficient health services cost (BPJS Kesehatan, 2014). This program encourages participants with chronic diseases with an indicator of $75 \%$ of registered participants visiting First Level Health Care Facility with type 2 diabetes mellitus type 2 and hypertension according to clinical guidelines, so it can prevent the occurrence of disease complications (BPJS Kesehatan, 2014). Complication prevention behaviors of hypertensive patients are doing physical activity, regulating diet, quitting smoking, taking medications regularly, maintaining weight, and controlling blood pressure regularly in health services (Perumareddi, 2019; Petrides et al., 2019).

One model of changes in health behavior is Health Belief Model (HBM). HBM is a method for knowing the basic healthy behavior of an individual. HBM consists of five constructs such as perceived vulnerability, perceived seriousness, perceived benefits, perceived barriers, cues to action, and self-efficacy (Sulaeman, 2017; Ma, 2018).

This study aimed to determine the effect of participation in chronic disease prevention program and the construction of Health Belief Model (HBM) which affects the hypertension control in the elderly.

\begin{tabular}{l}
\hline SUBJECTS AND METHOD \\
\hline a. Study Design \\
This study used observational analytical \\
study with retrospective cohort study \\
approach. The population was identified \\
into 2 groups, such as group which parti- \\
cipated in chronic disease prevention pro- \\
gram (case) and group which did not parti- \\
cipate in chronic disease prevention pro- \\
gram (control). This study was conducted \\
in four different community health centers \\
in Ngawi Regency, East Java, in April-May \\
2019. \\
b. Population dan Samples \\
The target population of this study was the \\
elderly aged 6o-74 years in four community \\
health centers, Ngawi Regency, East Java. \\
The community health centers were Jogo- \\
rogo, Teguhan, Paron, and Geneng commu-
\end{tabular}


nity health centers. A sample of 200 elderly aged 60-74 years was selected by fixed exposure sampling.

\section{c. Study Variables}

The dependent variable of this study was hypertension control. The independent variables in this study were participation in chronic disease prevention program, perceived vulnerability, perceived seriousness, perceived benefits, perceived barriers, cues to action, and self-efficacy.

\section{d. Operational Definition of Variables} Participation in chronic disease prevention program. Participation in chronic disease prevention program in medical consultation, health education, and gymnastics were carried out every one month. The data were collected by questionnaires. Scale of measurement was continuous. The scale was converted into a dichotomy for analyzing.

Perceived vulnerability. Perceived vulnerability was an assessment of the risk of hypertension. The data were collected by questionnaires. The scale of measurement was continuous. The scale was converted into a dichotomy for analyzing.

Perceived seriousness. Perceived seriousness was an assessment of the severity of hypertension. The data were collected by questionnaires. The scale of measurement was continuous. The scale was converted into a dichotomy for analyzing.

Perceived benefits. Perceived benefits were assessment of perceived benefits in carrying out health behaviors. The data were collected by questionnaires. The scale of measurement was continuous. The scale

was converted into a dichotomy for analyzing.

Perceived barriers. Perceived barriers were assessment of the obstacles to do health behaviors (cost, transportation, and distance). The data were collected by questionnaires. The scale of measurement was continuous. The scale was converted into a dichotomy for analyzing.

Cues to action. Cues to action was stimulation or encouragement to do health behaviors, such as family support, friends, and health workers. The data were collected by questionnaires. The scale of measurement was continuous. The scale was converted into a dichotomy for analyzing.

Self-efficacy. Self-efficacy was a belief on the ability to do health behaviors. The data were collected by questionnaires. The scale of measurement was continuous. The scale was converted into a dichotomy for analyzing.

Hypertension control. Hypertension control was activities which were conducted to prevent health complications such as doing physical activity, regulating diet, quitting smoking, and stop consuming alcohol. The data were collected by questionnaires. The scale of measurement was continuous. The scale was converted into a dichotomy for analyzing

\section{e. Study Instrument}

Data collection of independent and dependent variables was collected using a set of questionnaire.

\section{f. Data Analysis}

Univariate analysis described the characteristics of variables based on the results of the study. Bivariate analysis was conducted to determine the correlation between the dependent and independent variables using $\mathrm{t}$ test. Multivariate analysis used path analysis to determine the direct and indirect effects of a variable with 5 stages of path analysis (model specification, model identification, suitability model, parameter estimation, and model re-specification).

\section{g. Research Ethics}

Research ethics in this study include approval sheets, anonymity, confidentiality, and ethical feasibility. Ethical feasibility in this study came from the Health Research 
Journal of Health Promotion and Behavior (2019), 4(2): 85-97

https://doi.org/10.26911/thejhpb.2019.04.02.01

Ethics Committee in Dr. Moewardi Hospitalnumber: 448 / III / HREC / 2019.

\section{Univariate Analysis}

Table 1 and Table 2 show the characteristics of respondents and other variables, using continuous data and categorical data.

\begin{tabular}{lccccc}
\hline \multicolumn{2}{c}{ RESULTS } & & & & \\
\cline { 3 - 5 } Table 1. Sample characteristics (continuous data) & & & \\
\hline Characteristics & (n) & Mean & SD & Min. & Max. \\
\hline Hypertension control & 200 & 6.8 & 0.9 & 5 & 8 \\
Systolic blood pressure (mmHg) & 200 & 157.3 & 12.2 & 140 & 200 \\
Diastolic blood pressure (mmHg) & 200 & 92.5 & 4.3 & 90 & 100 \\
participation in chronic disease & 200 & 9.2 & 3.1 & 4 & 14 \\
prevention program & & & & & \\
Perceived vulnerability & 200 & 3.6 & 1.3 & 1 & 6 \\
Perceived seriousness & 200 & 4.4 & 1.2 & 2 & 6 \\
Perceived benefits & 200 & 4.3 & 1.2 & 1 & 5 \\
Perceived barriers & 200 & 3.9 & 1.1 & 2 & 5 \\
Cues to action & 200 & 3.2 & 0.8 & 1 & 4 \\
Self-efficacy & 200 & 2.9 & 1.3 & 1 & 5 \\
\hline
\end{tabular}

Table 2. Sample characteristic (categorical data)

\begin{tabular}{|c|c|c|}
\hline Variables & Frequency(n) & Percentage(\%) \\
\hline \multicolumn{3}{|l|}{ Hypertension control } \\
\hline Good (score $\geq 7)$ & 127 & 63.5 \\
\hline Poor $($ score $<7)$ & 73 & 36.5 \\
\hline \multirow{2}{*}{\multicolumn{3}{|c|}{$\begin{array}{l}\text { Participation in chronic } \\
\text { disease prevention program }\end{array}$}} \\
\hline & & \\
\hline \multicolumn{3}{|l|}{ Yes (score > 9) } \\
\hline \multirow[t]{2}{*}{ No $($ score $\leq 9)$} & 70 & 35 \\
\hline & 130 & 65 \\
\hline \multicolumn{3}{|l|}{ Perceived vulnerability } \\
\hline High (score $>4$ ) & 81 & 40.5 \\
\hline Low $($ score $\leq 4)$ & 119 & 59.5 \\
\hline \multicolumn{3}{|l|}{ Perceived seriousness } \\
\hline $\operatorname{High}($ score $>4)$ & 108 & 54 \\
\hline Low $($ score $\leq 4)$ & 92 & 46 \\
\hline \multicolumn{3}{|l|}{ Perceived benefits } \\
\hline High(score $>$ 4) & 147 & 73.5 \\
\hline Low $($ score $\leq 4)$ & 53 & 26.5 \\
\hline \multicolumn{3}{|l|}{ Perceived barriers } \\
\hline High(score $>4)$ & 99 & 49.5 \\
\hline Low(score $\leq 4)$ & 101 & 50.5 \\
\hline \multicolumn{3}{|l|}{ Cues to action } \\
\hline High(score> 3) & 91 & 45.4 \\
\hline Low $($ score $\leq 3)$ & 109 & 54.5 \\
\hline \multicolumn{3}{|l|}{ Self-efficacy } \\
\hline High (score> 3 ) & 62 & 31 \\
\hline Low $($ score $\leq 3)$ & 138 & 69 \\
\hline
\end{tabular}

Tables 1 and 2 show that the study subjects who had lower perceived vulnerability were119 people (59.5\%). Meanwhile, the study subjects who had a high perceived vulnerability were 81 people (40.5\%). The study subjects who had higher perceived 
Aprilia et al./ The Effectiveness of Chronic Disease Prevention

seriousness were 108 people (54\%). Meanwhile, the study subjects who had low perceived seriousness were 92 people (46.5\%). The study subjects who had low cues to action were 109 people (54.5\%). Meanwhile, the study subjects who had high cues to action were 91 people $(45 \cdot 5 \%)$. The study subjects who had lower selfefficacy were 138 people. The study subjects with good hypertension control were 127 people (63.5\%). Meanwhile, the study subjects with poor hypertension control were 73 people (36.5).

\section{Bivariate Analysis}

Bivariate analysis explained the effects of one independent variable on one dependent variable. The analytical method used was the $t$ test which showed the results of participation in chronic disease prevention program (Mean difference $=-3,5 ; \mathrm{p}<0.001$ ), perceived vulnerability (Mean difference $=$ 1.5; $\mathrm{p}<0.001$ ), perceived seriousness (Mean difference $)=-1 ; \mathrm{p}<0.001) \quad($ Mean difference $=-1 ; \mathrm{p}<0.001)$, perceived barriers(Mean difference $=0.9 ; \mathrm{p}<0.001)$, cues to action (Mean difference $=-0.4 ; \mathrm{p}<0.001$ ), and selfefficacy (Mean difference $=-0.4 ; p=0.002$ ).

Table 3 The $t$ test on the correlation between independent and dependent variables

\begin{tabular}{|c|c|c|c|c|c|}
\hline Variables of the study & $\begin{array}{c}\text { Hypertension } \\
\text { control }\end{array}$ & $\mathbf{N}$ & Mean & $\begin{array}{c}\text { Mean } \\
\text { diff }\end{array}$ & $\mathbf{p}$ \\
\hline \multirow[t]{2}{*}{$\begin{array}{l}\text { Participation in chronic disease } \\
\text { prevention program }\end{array}$} & Good & 127 & 7 & -3.5 & $<0.001$ \\
\hline & Poor & 73 & 10.5 & & \\
\hline \multirow[t]{2}{*}{ Perceived vulnerability } & Good & 127 & 2.6 & -1.5 & $<0.001$ \\
\hline & Poor & 73 & 4.1 & & \\
\hline \multirow[t]{2}{*}{ Perceived seriousness } & Good & 127 & 3.7 & -1 & $<0.001$ \\
\hline & Poor & 73 & 4.8 & & \\
\hline \multirow[t]{2}{*}{ Perceived barriers } & Good & 127 & 3.5 & 0.9 & $<0.001$ \\
\hline & Poor & 73 & 4.4 & & \\
\hline \multirow[t]{2}{*}{ Cues to action } & Good & 127 & 3.4 & -0.4 & $<0.001$ \\
\hline & Poor & 73 & 2.9 & & \\
\hline Self-efficacy & Good & 127 & 3 & -0.4 & 0.002 \\
\hline
\end{tabular}

\section{Path Analysis}

\section{a. Model Specification}

Model specification described the correlation between the variables studied. In this study, there were eight observed variables, such as participation in chronic disease prevention program, perceived vulnerability, perceived seriousness, perceived benefits, perceived barriers, cues to action, self-efficacy, and hypertension control.

\section{b. Model Identification}

The observed variables were:

1) Number of observed variables $: 8$

2) Endogenous variables :2

3) Exogenous variables : 6

4) Number of parameter :8
Degree of freedom (df) $=$ number of observed variables $\mathrm{x}$ (number of observed variables +1$) / 2-($ endogenous variables + exogenous + number of parameter)

$\mathrm{df}=(72 / 2)-(16)$

$\mathrm{df}=36-16$

$\mathrm{df}=20$

The result ofdegree of freedom (df)was 20, which means that the over identifiedof path analysis could be conducted.

Table 4 shows the result of path analysis. Table 4 shows that hypertension control was directly affected by participation in chronic disease prevention program, perceived vulnerability, perceived seriousness, and self-efficacy. The elderlies who 
Journal of Health Promotion and Behavior (2019), 4(2): 85-97

https://doi.org/10.26911/thejhpb.2019.04.02.01

participated in chronic disease prevention program had logodd of good hypertension control 2.85 units higher than the elderlies who did not participate in chronic disease prevention program $(\mathrm{b}=2.85 ; 95 \% \mathrm{CI}=$ 0.48 to $5.22 ; p=0.018$ ). The elderlies with high perceived vulnerability had logodd of good hypertension control 1.35 units higher than the elderlies with low perceived vulnerability $(b=1.35 ; 95 \% \mathrm{CI}=0.16$ to 2.53; $\mathrm{p}=0.025$ ). The elderlies with high perceived seriousness had logodd of good hypertension control 0.83 units higher than the elderlies with low perceived seriousness $(\mathrm{b}=0.83 ; 95 \% \mathrm{CI}=0.04$ to1.62; $\mathrm{p}=0.039$ ). The elderlies with high self-efficacy had logodd of good hypertension control 0.99 units higher than the elderlies with low selfefficacy $(b=0.99 ; 95 \% \mathrm{CI}=0.14$ to1.85; $\mathrm{p}=$ 0.023).

Hypertension control was indirectly affected by perceived benefits, perceived barriers, and cues to action.

Perceived benefits affected hypertension control through participation in chronic disease prevention program, perceived vulnerability, and self-efficacy. The elderlies with high perceived benefits had logodd of participated in chronic disease prevention program 2.48 units higher than the elderlies who did not participate in chronic disease prevention program $(\mathrm{b}=$ $2.48 ; 95 \% \mathrm{CI}=0.88$ to $4.09 ; \mathrm{p}<0.001)$. The elderlies with high perceived benefits had logodd of high perceived vulnerability 1.24 units higher than the elderlies with low perceived vulnerability $(b=1.24 ; 95 \% \mathrm{CI}=$ 0.50 to $1.98 ; \mathrm{p}=0.001$ ). The elderlies with high perceived benefits had logodd of high self-efficacy 1.18 units higher than the elderlies with low self-efficacy $(b=1.18$; $95 \% \mathrm{CI}=0.36$ to $2.00 ; \mathrm{p}=0.005$ ).

Perceived barriers indirectly affected hypertension control through participation in chronic disease prevention program and cues to action. The elderlies with high perceived barriers had logodd of participated in chronic disease prevention program 4.15 units lower than the elderlies who did not participate in chronic disease prevention program $(b=-4.15 ; 95 \% \mathrm{CI}=-5.47$ to -2.84 ; $\mathrm{p}<0.001)$. The elderlies with high perceived barriers had logodd of cues to action 2.02 units higher than the elderlies with low cues to action ( $b=-2.02 ; 95 \% \mathrm{CI}=-2.65$ to 1.38; $\mathrm{p}<0.001$ ).

Cues to action indirectly affected hypertension control through perceived seriousness. The elderlies with high cues to action had logodd of perceived seriousness 1.76 units higher than the elderlies with low perceived seriousness $(\mathrm{b}=1.76 ; 95 \% \mathrm{CI}=$ 0.99 to $2.53 ; \mathrm{p}=<0.001$ ).

Perceived seriousness indirectly affected hypertension control through perceived vulnerability. The elderlies with high perceived vulnerability had logodd of high perceived seriousness 1.62 units higher than the elderlies with low perceived seriousness $(\mathrm{b}=1.62 ; 95 \% \mathrm{CI}=0.81$ to 2.44 ; $\mathrm{p}<0.001)$.

Self-efficacy indirectly affected hypertension control through participation in chronic disease prevention program. The elderlies with high self-efficacy had logodd of participated in chronic disease prevention program 1.16 units higher than the elderlies who did not participate in chronic disease prevention program $(b=1.16 ; 95 \%$ $\mathrm{CI}=0.18$ to $2.14 ; \mathrm{p}<0.001)$. 
Aprilia et al./ The Effectiveness of Chronic Disease Prevention

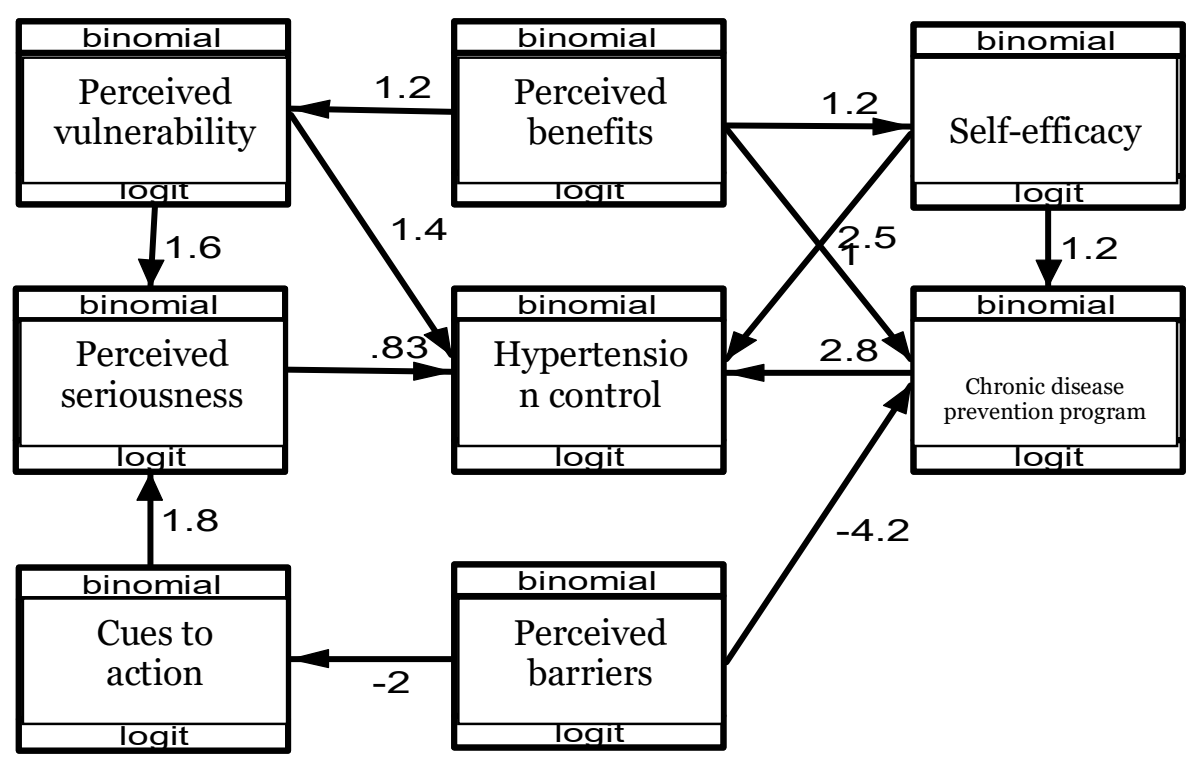

Figure 1.The structural model of path analysis

Table 4. The result of path analysis of chronic disease prevention program on hypertension control

\begin{tabular}{llcccc}
\hline \multirow{2}{*}{ Dependen variables } & Independent variables & b & \multicolumn{2}{c}{ CI (95\%) } & Lower \\
\cline { 5 - 6 } & & & $\begin{array}{c}\text { Upper } \\
\text { limit }\end{array}$ & p \\
\hline Direct effect & limit & \\
Hypertension control & $\leftarrow$ Participation & 2.85 & 0.48 & 5.22 & 0.018 \\
& $\leftarrow$ Perceived vulnerability & 1.35 & 0.17 & 2.53 & 0.025 \\
& $\leftarrow$ Perceived seriousness & 0.83 & 0.04 & 1.62 & 0.039 \\
& $\leftarrow$ Self-efficacy & 0.99 & 0.14 & 1.85 & 0.023 \\
Indirect effect & $\leftarrow$ Perceived barriers & -4.15 & -5.47 & -2.84 & $<0.001$ \\
Participation & $\leftarrow$ Perceived benefits & 2.48 & 0.88 & 4.09 & $<0.001$ \\
& $\leftarrow$ Self-efficacy & 1.16 & 0.18 & 2.14 & $<0.001$ \\
Perceived vulnerability & $\leftarrow$ Perceived benefits & 1.24 & 0.50 & 1.98 & 0.001 \\
Perceived seriousness & $\leftarrow$ Perceived vulnerability & 1.62 & 0.81 & 2.44 & $<0.001$ \\
& $\leftarrow$ Cues to action & 1.76 & 0.99 & 2.53 & $<0.001$ \\
Cues to action & $\leftarrow$ Perceived barriers & -2.02 & -2.65 & -1.38 & $<0.001$ \\
Self-efficacy & $\leftarrow$ Perceived benefits & 1.18 & 0.36 & 2.00 & 0.005 \\
N observation $=200$ & & & & & \\
Log likelihood $=-616.15$ & & & & & \\
\hline
\end{tabular}

\section{DISCUSSION}

\section{The Effects of Chronic Disease Pre- vention Program on Hypertension Control}

The result of this study indicated that chronic disease prevention program had direct and positive effects on hypertension control which were statistically significant.
Chronic disease prevention program is a health service and proactive system in maintaining the health of chronic sufferers to achieve optimal quality of life (BPJS Kesehatan, 2014).

Based on a study conducted by Dyanneza et al. (2017), chronic disease prevention program as a government program 
Journal of Health Promotion and Behavior (2019), 4(2): 85-97

https://doi.org/10.26911/thejhpb.2019.04.02.01

to improve hypertension control which includes blood pressure monitoring, gymnastics, home visits, and health education has effects on controlling blood pressure in hypertensive patients.

Efforts to control hypertension are important to prevent complications of cardiovascular disease. Managing a healthy lifestyle can be used as a basis for controlling hypertension (Mills et al., 2016).

Physical activity such as gymnastic in chronic disease prevention program activities can be used to control the blood pressure of hypertensive patients, thus reducing blood pressure (Mills et al., 2016).

Home visit is one of the activities in chronic disease prevention program. The result of a study conducted by Dyanneza et al. (2017) showed that there was a statistically significant effect of home visits on systolic blood pressure in hypertensive patients. Hypertensive patients who received home visits had systolic blood pressure $22 \mathrm{mmHg}$ lower than hypertensive patients who did not receive home visits.

Every individual has different affordability on medicine and health care, so that the government creates an effective healthbased program to expand public health services, especially at the primary care level. The basis of this effective program is adopting a healthy lifestyle to prevent, treat, and control public health, especially for people with hypertension (Yang et al., 2016; Setiyaningsih et al., 2017)

Schiffrin et al. (2016) explains that the availability of public health systems by the government can be used effectively to control blood pressure in hypertensive patients. The development of a hypertension control program in Canada is called the Canadian Hypertension Education Program (CHEP) which is designed to increase blood pressure monitoring. The Canadian Hypertension Education Program recommends the health workers to use electronic devices (oscillometrics) specifically in measuring blood pressure rather than manual auscultation to improve the accuracy of blood pressure measurements, especially in hypertensive patients.

\section{The Effects of Perceived Vulne- rability on Hypertension Control}

The result of this study indicated that there were direct and positive effects of perceived vulnerability on hypertension control which were statistically significant. Perceived vulnerability also indirectly affected hypertension control through perceived seriousness.

This study is in line with a study by Noumani et al. (2019) that patient's beliefs about health, vulnerability to a disease, and ways of health care have effects on medication adherence as one of the controls for chronic diseases including hypertension.

According to Setiyaningsih et al. (2017), there is an indirect effect between perceived vulnerability and hypertensive prevention behavior. Perceived vulnerability refers to subjective assessment of risks for health problems. The belief that she/he is susceptible to diseases that can threaten health will encourage individual to conduct health behaviors in preventing the occurrence of the disease complications (Puspita et al., 2017).

This is in accordance with the theory of Health Belief Model developed by Rosenstock (1994) that the individual assumption of getting a disease will make them aware of the prevention and protection (Murti, 2018). HBM illustrates a person who has a perception that he is susceptible to experience a disease will have a greater possibility of taking action to prevent the occurrence of the disease. However, a person who has a low perceived vulnerability to experience a disease has 
low possibility to take action to prevent the occurrence of disease. These individuals are more likely to engage unhealthy or risky behavior (Murti, 2018).

\section{The Effects of Perceived Serious- ness on Hypertension Control}

The result of this study indicated that there were direct and positive effects of perceived seriousness on hypertension control which were statistically significant.

The result of this study is in line with a study conducted by Al-Noumani et al. (2019) that the seriousness felt by an individual can affect the prevention and treatment of a disease. One of the diseases is hypertension because hypertension does not show symptoms like other diseases.

Perceived seriousness refers to a individual subjective assessment of the severity of a disease and the potential which can occurs if it is not treated or prevented. Someone who considers a disease seriously, will has a greater possibility to take an action needed to prevent the occurrence of the disease, or reduce the severity (Murti, 2018). The construction of perceived seriousness concerns the individual's beliefs about the seriousness or severity of the disease. Meanwhile, perceived seriousness is often based on medical information or knowledge. It can also come from a individual's belief that she/he will get difficulties due to disease and it affects on her/his life (Sulaeman, 2017).

\section{The Effects of Self-Efficacy on Hypertension Control}

The result of this study indicated that there were direct and positive effects of selfefficacy on hypertension control which were statistically significant. Self-efficacy also has indirect and positive effects on hypertension control through chronic disease prevention program.

Based on a study conducted by Setiyaningsih et al. (2017), self-efficacy increases control of individual's behavior in doing health behaviors. Self-efficacy refers to individual's belief which can estimate her/ his ability to take action needed to achieve certain results.

Based on a study conducted by Yue et al. (2015), self-efficacy significantly affected the control of a disease. Every single unit that increases self-efficacy will improve hypertension prevention behavior (Puspita et al., 2017).

High self-efficacy affects someone to do physical activity, regulate diet as a form of health behavior change (Yang et al., 2016). The effectiveness of a disease control health program can be improved by strategies to adjust the ability to change individual's personal health behavior (Schiffrin et al., 2016).

\section{The Effects of Perceived Benefits on Hypertension Control}

The result of this study indicated that there were indirect and positive effects of perceived benefits on hypertension control through perceived vulnerability which were statistically significant. Perceived benefits have indirect and positive correlation on hypertension control through self-efficacy which were statistically significant. Perceived benefits were also indirectly and positively related to hypertension control through chronic disease prevention program which were statistically significant. Based on a study conducted by Setiyaningsih et al. (2017), benefits felt by someone have positive effects on hypertension control behavior.

The theory of Health Belief Model states that behavior which is related to health is also affected by an individual's perception of the benefits of taking healthy actions or behaviors. The benefits felt by an individual will affect preventive action (Murti, 2018). The perceived benefits refer to an individual's assessment of value or 
Journal of Health Promotion and Behavior (2019), 4(2): 85-97

https://doi.org/10.26911/thejhpb.2019.04.02.01

involvement in promoting health behavior to reduce the risk of disease. If an individual believes that certain actions can reduce vulnerability on health problems or reduce seriousness, the individual tends to engage in behavior, aside from objective facts about the effectiveness of an action (Sulaeman, 2016).

Based on a study conducted by Yue et al. (2015), perceived benefits show significant results on the prevention of a disease. Increasing perceived benefits to avoid a disease can affect on improving individual's self-efficacy, so that the tendency of someone's ability in health behavior will be better.

\section{The Effects of Perceived Barriers on Hypertension Control}

The result of this study indicated that there were indirect and negative effects of perceived barriers on hypertension control through cues to action which were statistically significant.

The result of this study is in line with Setiyaningsih et al. (2016) that perceived barriers have negative effects which are statistically significant on hypertension control behavior.

Another study conducted by Yue et al. (2015) explains that perceived barriers significantly affect medication adherence as a form of hypertension control.

Perceived barriers refer to various factors, including costs, transportation, and discomfort feeling which affect an individual in doing health behaviors. Reducing perceived barriers can be used as a basis for increasing the effectiveness of a disease prevention program (Puspita et al., 2017).

\section{The Effects of Cues to action on Hypertension Control}

The result of this study indicated that cues to action were indirectly and positively related to hypertension control through perceived seriousness which was statistically significant.

The result of this study is in line with a study conducted by Yue et al. (2015) that cues to act significantly affect medication adherence as a form of hypertension control.

Cues to action are needed to encourage individual involvement in health behavior. Cues to action can come from internal and external factors. Internal factors are symptoms or health complaints. External factors are information from friends, family, health workers, and media (Setiyaningsih et al., 2017).

Based on a study conducted by Yue et al. (2016), external factors such as social support from families and health workers increase an individual's belief in doing health behavior. Elderly people who get family support have better health behaviors. Support from family and health workers can be used as a health promotion strategy in controlling a disease (Jannah et al., 2018).

HBM shows that behavior is affected by cues to action. Cues to action are events, people, or things that move to change behavior (Sulaeman, 2016). Cues to action are encouragement to do health behavior (Murti, 20-18).

\section{AUTHORS CONTRIBUTION}

Nafi'ah Aprilia is the main researcher who plays a role in collecting and processing the data of the study. Didik Gunawan Tamtomo examined the conceptual framework and methodology of the study. Endang Sutisna Sulaeman examined data analysis and interpretation of the results of the analysis.

FUNDING AND SPONSORSHIP

There is no external funding. 
Aprilia et al./ The Effectiveness of Chronic Disease Prevention

\section{CONFLICT OF INTEREST}

There was no conflict of interest.

\section{ACKNOWLEDGEMENT}

We thank the community health centers in Ngawi Regency and the officers who helped the research and the study subjects who have participated and have been willing to be the study subjects.

\section{REFERENCES}

Al-Noumani, Wu H, Barksdale JR, Sherwood D, AlKhasawneh G, Knafl E, George (2019). Health beliefs and medication adherence in patients with hypertension: a systematic review of quantitative studies. Patient Education and Counseling: Patient EducCouns, 102(6): 1045-1056. Retrieved from https://doi.org/10.1016/j.pec.2019.02.022

Asibey,Yeboah OA, Owiredu F, AcheampongWKBA, Anto EO,Owusu E, Isaac K (2018). Interplay of adipokines in the pathogenesis of essential hypertension: a comparative cross-sectional in Ghana.Alexandria Journal of Medicine, 54(4): 469-474. doi:10.1016/j.ajme.2018.07.004.

BPJS Kesehatan (2014).Panduan praktis prolanis (program pengelolaan penyakit kronis). Retrieved from https://bpjs-kesehatan.go.id/bpjs/dmdocuments/o6-PROLANIS.pdf

Chen, $\mathrm{Hu}$ ML, Jie (2014). Health disparities in Chinese Americans with hypertension: a review. International Journal of Nursing Sciences, 1(3): 318-322.doi:10.1016/j.ijnss.2014.07.002.

Dinas Kesehatan Kabupaten Ngawi (2018). Profil kesehatan Kabupaten Ngawi tahun 2017. Ngawi. Retrieved from http://www.depkes.go.id/resources/download/profil/PROFIL_KAB_KOTA_ 2017/3521_Jatim_Kab_Ngawi_2017. pdf

Dinas Kesehatan Provinsi Jawa Timur (2018). Profil kesehatan Provinsi Jawa Timur tahun 2018.Surabaya. Retrieved from:http://www.depkes.go.id/resources/download/profil/PROFIL_ KES_PROVINSI_2017/15_Jatim_2O 17.pdf

Du, Shih Y, Lightstone M, Baldwin AS, Susie (2017). Hypertension amongAsians in Los Angeles County: findings from a multiyear survey. Preventive Medicine Reports: Prev Med Rep,6: 302-306. doi: 10.1016/j.pmedr.2017.03.009 .

Goong H, Ryu S, Xu L (2016).A structural model of health behavior modification among patients with cardiovascular disease. Applied Nursing Research: Appl Nurs Res, 29: 70-75. doi: 10.1016/j.apnr.2015.06.005.

JannahN, Tamtomo D, Soemanto R (2018). Factors associated with healthy preventive behavior among the elderly in Lamongan, east java.Journal of Health Promotion and Behavior: J. Health Promot Behav, 3(4): 223-229. doi: 10.26911/thejhpb.2018.03.04.01.

Kementerian Kesehatan RI (2018). Riset kesehatan dasar. Jakarta: Badan Litbang Kemenkes RI. Retrieved from http://www.depkes.go.id/resources/d ownload/infoterkini/materi_rakorpp _2018/Hasil\%20Riskesdas\%202018. pdf?opwvc $=1$

$\mathrm{MaC}(2018)$. An investigation of factors influencing self-care behaviors in young and middle-aged adults with hypertension based on a health belief model. Heart and Lung: Heart Lung, 47(2): 136-141. doi:10.1016/j.hrtlng.2017.12.001.

Mills KT, Bundy KT, Kelly JD, Reed TN, Kearney JE, Reynolds PM, Chen K, He J (2016). Global disparities of hy- 
Journal of Health Promotion and Behavior (2019), 4(2): 85-97

https://doi.org/10.26911/thejhpb.2019.04.02.01

pertension prevalence and controlclinical perspective.Circulation: Circulation, 134(6): 441-450.doi:10.1161/CIRCULATIONAHA.115.018912.

Murti B (2018). Teori promosi dan perilaku kesehatan. Karanganyar: Bintang Fajar Offset.

Perumareddi P (2019). Prevention of hypertension related to cardiovascular disease. Primary Care: Prim Care, 46(1):27-39. doi:10.1016/j.pop.2018.10.005 .

Petersen J, Benzeval M (2016). Untreated hypertension in the UK household population - Who are missed by the general health checks?.Preventive Medicine Reports: Prev Med Rep, 4: 81-86. doi: 10.1016/j.pmedr.2016.05.007.

Petrides, Collins J, Kowalski P, Sepede A,Vermeulen J, Meagan(2019). Lifestyle changes for disease prevention.Primary Care: Prim Care, 46(1): 1-12. doi: 10.1016/j.pop.2018.10.003.

Puspita RC, Tamtomo D, Indarto D (2017). Health belief model for the analysis of factors affecting hypertension preventive behavior among adolescents in Surakarta.Journal of Health Promotion and Behavior: J. Health Promot Behav, 2(2): 183-196. doi:10.26911/thejhpb.2017.02.02.08.

Puspitosari A, Soemanto R, Wijaya M (2017). Factors associated with exercise among elderly in Boyolali, Indonesia. Journal of Health Promotion and Behavior: J. Health Promot Behav, 1(1): 41-45.doi:10.26911/thejhpb.2016.01.01.06.

Savitri D (2017). Diam-diam mematikan cegah asam urat dan hipertensi. Bantul: PT Remaja Rosdakarya.

Schiffrin, Campbell EL,Feldman NRC,Kaczorowski RD,Lewanczuk J, Padwal R, Raj, Tobe R, Sheldon W (2016). Hypertension in Canada: Past, Present, and Future. Annals of Global Health: Ann Glob Health, 82(2): 288-299.doi: 10.1016/j.aogh.2016.02.006.

Setiyaningsih R, Tamtomo D, SuryaniN (2017). Health belief model: determinantsof hypertension prevention behaviorinadults at community health center, Sukoharjo, Central java. Journal of Health Promotion and Behavior: J. Health Promot Behav, 1(3): 160-170. doi: 10.26911/thejhpb.2016.01.03.03.

Shafi ST, Shafi T (2017). A survey of hypertension prevalence, awareness, treatment, and control in health screening camps of rural Central Punjab, Pakistan. Journal of Epidemiology and Global Health: J Epidemiol Glob Health, 7(2): 135-140. doi: 10.1016/j.jegh.2017.01.001.

Sulaeman ES (2016). Pembelajaran model dan teori perilaku kesehatan konsep dan aplikasinya. Surakarta: UNS Press.

Sulaeman ES (2017). Model perencanaan promosi kesehatan dan pemberdayaan (studi kasus program pencegahan dan penanggulangan penyakit demam berdarah dengue dan tuberkulosis). Surakarta: UNS Press.

Susilo Y, Wulandari A (2011). Cara jitu mengatasi hipertensi. Yogyakarta:Andi offset.

Triyanto D (2014). Pelayanan keperawatan bagi penderita hipertensi. Yogyakarta: Graha ilmu.

Yang, He S, Zhang C, Sun X, Wu K, Sun S, Li X, Yindong (2016). Determinants of antihypertensive adherence among patients in Beijing: Application of the health belief model.Patient Education and Counseling: Patient Educ Couns, 99(11): 1894-1900. doi:10.1016/j.pec.2016.06.014.

Yoo, Park MG, Kim KJ, Jang HJ, Lee HB, 
Park HJ, Ick S (2019). Association between alcohol intake and incident hypertension in the Korean population. Alcohol: Alcohol, 77: 19-25. doi:10.1016/j.alcohol.2018.09.002.

Youssef, Nagy G, El S ,Aal AA, Hamid A, Abdel M (2018). Masked uncontrolled hypertension: prevalence and predictors. Egyptian Heart Journal: Egypt Heart J, 70(4): 369-373. doi: 10.1016- /j.ehj.018.10.001.

Yue, Li Z, Weilin C, Bin Q, Wang (2015). Application of the health belief model to improve the understanding of antihypertensive medication adherence among Chinese patients. Patient Education and Counseling: Patient Educ Couns, 98(5): 669-673. doi: 10.1016/j.pec.2015.02.007. 